\title{
Non-cardiac causes of cardiac tamponade
}

\author{
Amr Mohsen, ${ }^{1}$ Karim El-Kersh ${ }^{2}$
}

${ }^{1}$ Department of Cardiovascular Medicine, University of Louisville, Louisville,

Kentucky, USA

${ }^{2}$ Department of Pulmonary, Critical Care \& Sleep Medicine, University of Louisville, Louisville, Kentucky, USA

\section{Correspondence to} Dr Amr Mohsen, a0mohs01@louisville.edu
To cite: Mohsen A, El Kersh K. BMJ Case Rep Published online: [please include Day Month Year] doi:10.1136/bcr-2013010170

\section{DESCRIPTION}

A 60-year-old man with diffused large B-cell lymphoma undergoing chemotherapy presented with dyspnoea. He had a borderline hypotensive blood pressure of $106 / 75 \mathrm{~mm} \mathrm{Hg}$ and a heart rate around $105 \mathrm{bpm}$. Chest X-ray and CT of the chest showed large right pleural effusion (figures 1 and 2). A transthoracic echocardiogram demonstrated no pericardial fluid, however there was invagination of the right atrial free wall with tamponade physiology caused by the right pleural effusion (figures 3 and 4; videos 1 and 2). Therapeutic thoaracentesis with the removal of $1.9 \mathrm{~L}$ of transudative fluid was performed after which the patient had complete resolution of the tamponade physiology (figures 5 and 6; videos 3 and 4) and

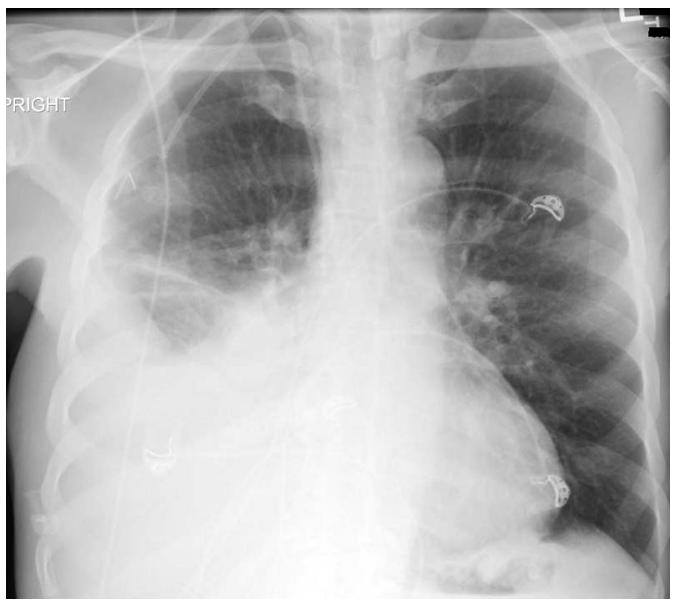

Figure 1 Chest roentgenogram showing obliteration of the right costophrenic angle consistent with a right pleural effusion.

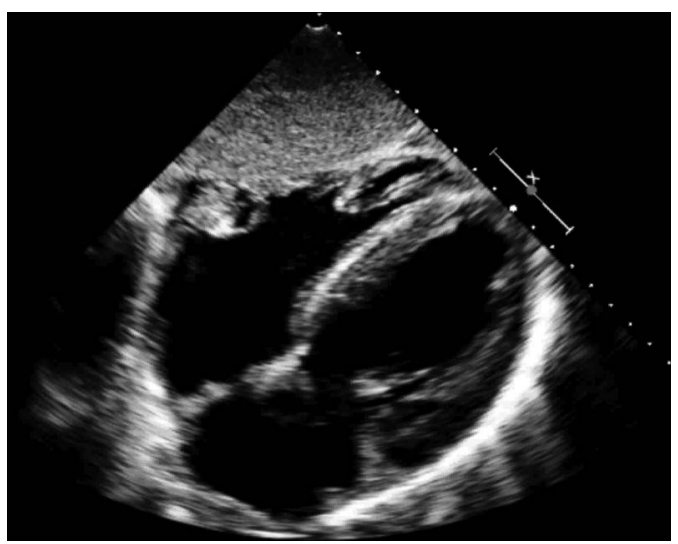

Figure 2 CT of the chest demonstrating large right pleural effusion displacing the heart to the left side.

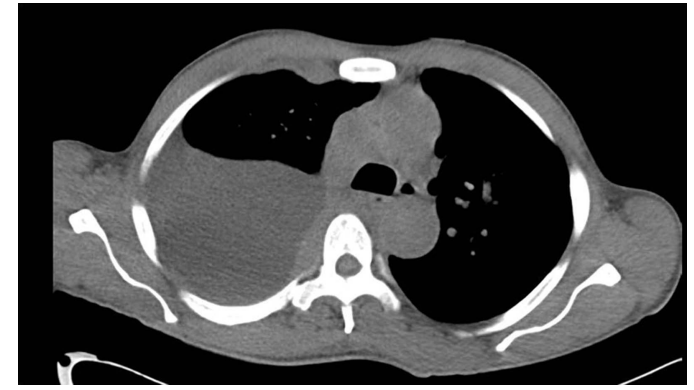

Figure 3 Transthoracic echocardiogram, the four-chamber view, demonstrating invagination of the right atrial free wall with tamponade physiology.

dyspnoea with an improvement of borderline hypotension and tachycardia.

Cardiac tamponade encompasses a spectrum that ranges from mild to severe cardiac compression. Tamponade progression depends on the intrapericardial pressure, intracavitary pressure and chamber wall compliance. The right atrium is the first to collapse followed by the left atrium and the right ventricular free wall, respectively. ${ }^{1}$ Diastolic collapse of the right atrium in end diastole, especially when it persists for more than one-third of the cardiac cycle, is highly sensitive and specific for cardiac tamponade. ${ }^{2}$

Using canine models exposed to pericardial and pleural fluid infusion, the rise in pericardial pressure secondary to pleural effusion was found to be better tolerated than the rise to the same level when caused by a pericardial effusion only. ${ }^{1}$ Coexistence of pericardial and pleural effusions can result in a challenging therapeutic decision when the echocardiogram shows findings suggestive of cardiac tamponade.

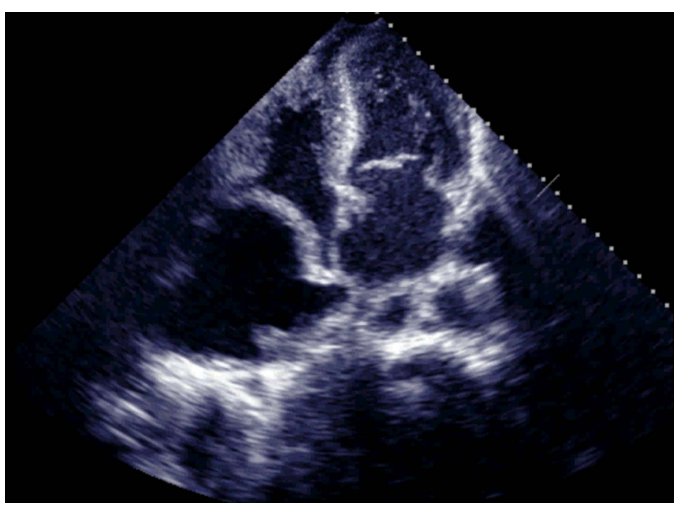

Figure 4 Transthoracic echocardiogram, the subcostal view demonstrating invagination of the right atrial free wall with tamponade physiology. 


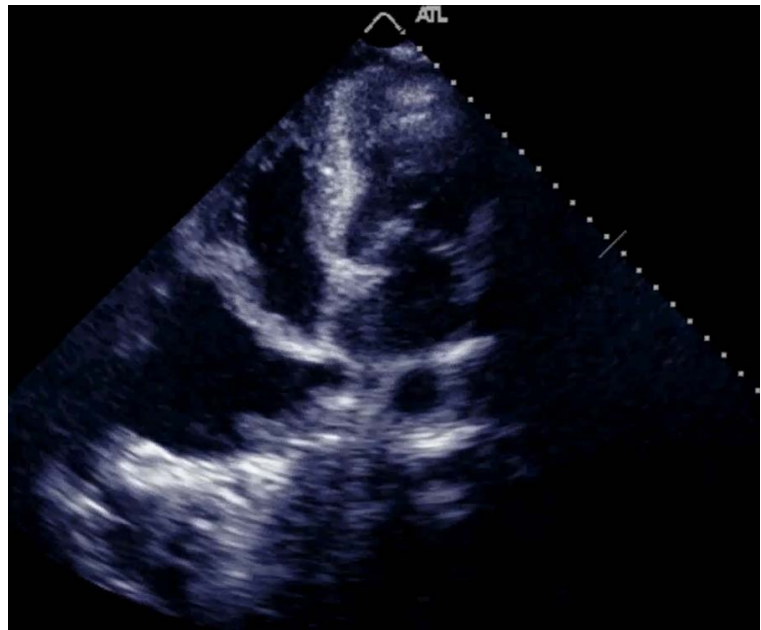

Video 1 Transthoracic echocardiogram, four-chamber view, demonstrating invagination of the right atrial free wall with tamponade physiology.

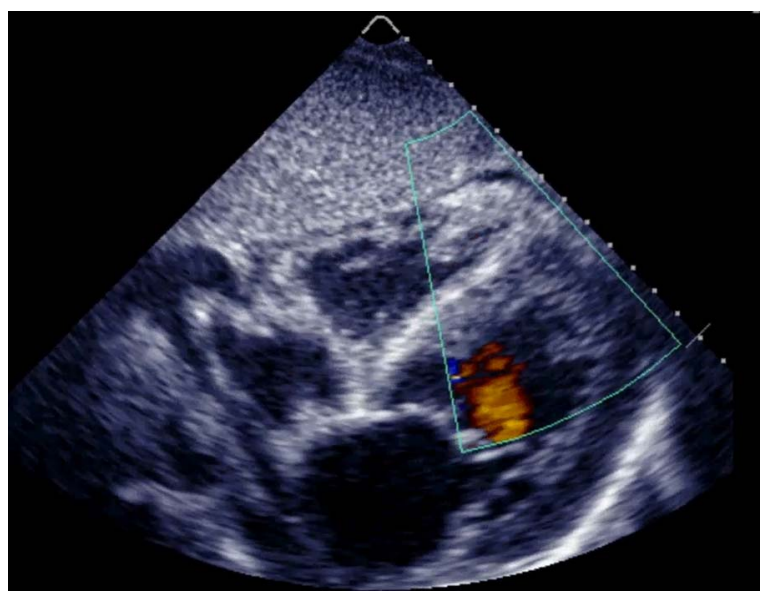

Video 2 Transthoracic echocardiogram, subcostal view demonstrating invagination of the right atrial free wall with tamponade physiology.

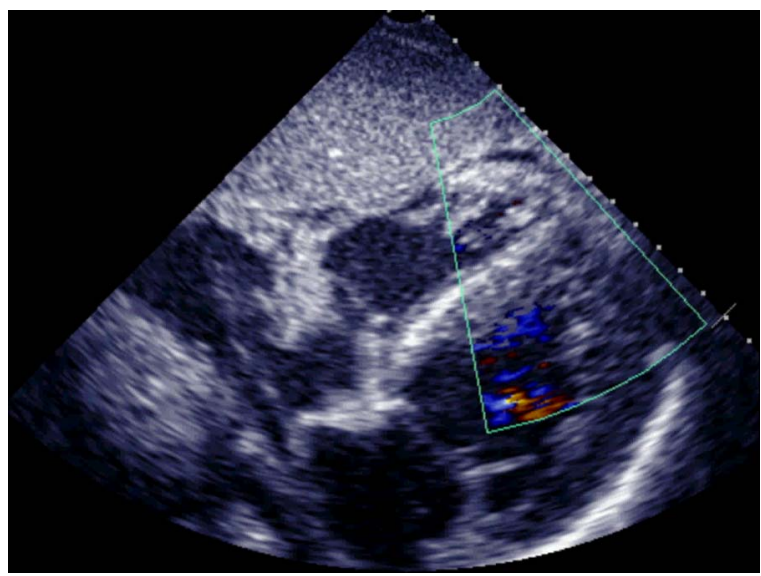

Figure 5 Transthoracic echocardiogram, the four-chamber view demonstrating resolution of tamponade physiology after thoracentesis.

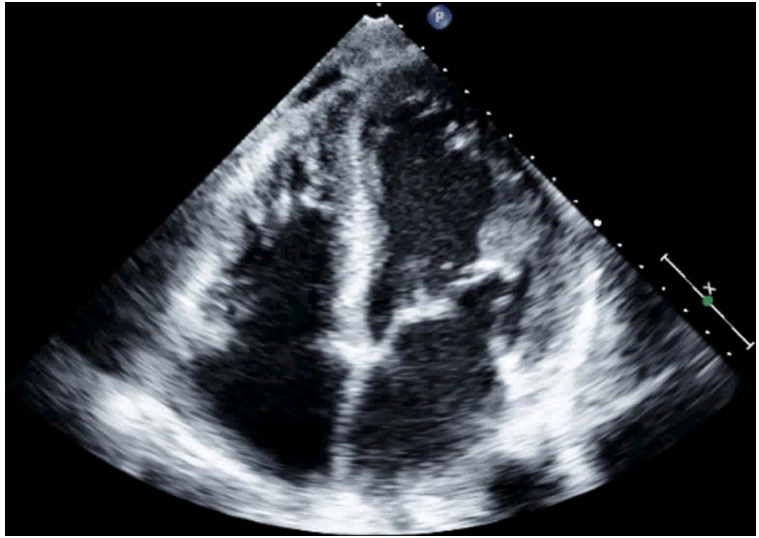

Figure 6 Transthoracic echocardiogram, the subcostal view demonstrating resolution of tamponade physiology after thoracentesis.

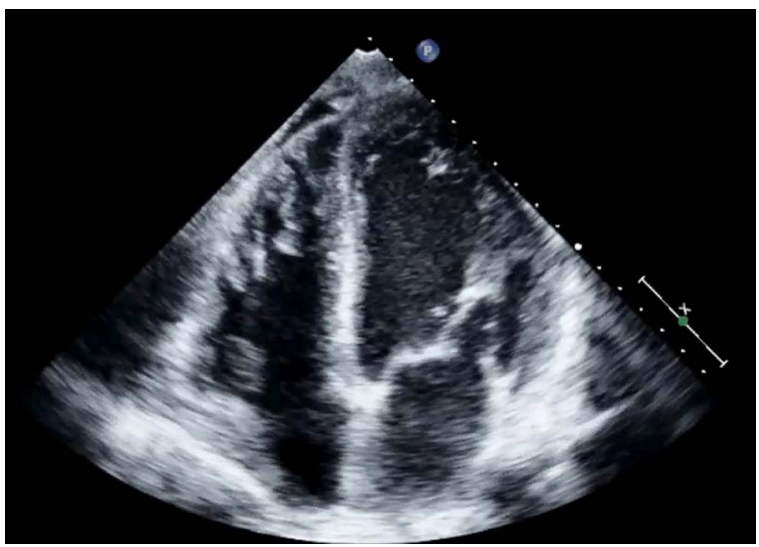

Video 3 Transthoracic echocardiogram, four-chamber view demonstrating resolution of tamponade physiology after thoracentesis.

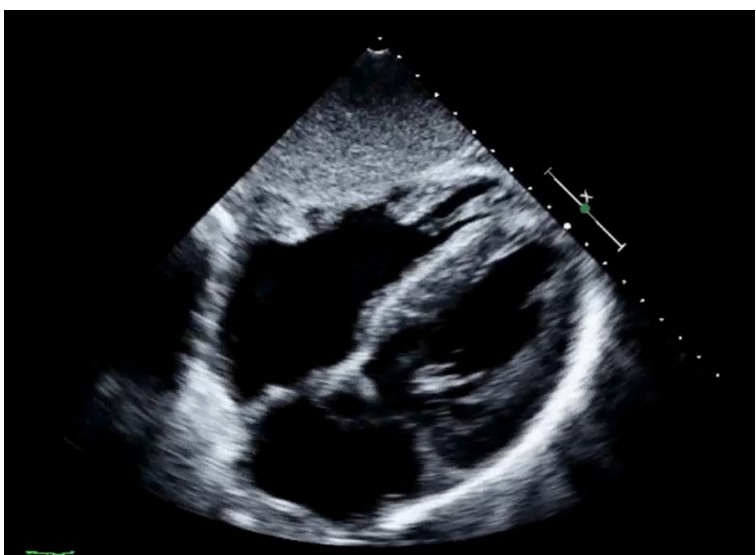

Video 4 Transthoracic echocardiogram, subcostal view demonstrating resolution of tamponade physiology after thoracentesis. 


\section{Learning points}

- Cardiac tamponade is caused by compression of cardiac chambers due to increased pericardial pressure.

- Large pleural effusion may cause an increased intrapericardial pressure sufficiently to cause echocardiographic findings of cardiac tamponade. In this situation, the appropriate therapeutic approach is the drainage of the pleural effusion.

Contributors The article represents the original work of the stated authors and has not been submitted elsewhere for publication. Co-authors of the present article participated in its preparation, meet the full criteria and requirements for authorship and are willing to sign a statement attesting authorship and releasing the copyright should the manuscript be acceptable. All authors have read and approved the manuscript.

Competing interests None.

Patient consent Obtained.

Provenance and peer review Not commissioned; externally peer reviewed.

\section{REFERENCES}

1 Klopfenstein HS, Wann LS. Can pleural effusions cause tamponade-like effects? Echocardiography 1994;11:489-92.

2 Gillam LD, Guyer DE, Gibson TC, et al. Hydrodynamic compression of the right atrium: a new echocardiographic sign of cardiac tamponade. Circulation 1983;68:294.

Copyright 2013 BMJ Publishing Group. All rights reserved. For permission to reuse any of this content visit http://group.bmj.com/group/rights-licensing/permissions.

BMJ Case Report Fellows may re-use this article for personal use and teaching without any further permission.

Become a Fellow of BMJ Case Reports today and you can:

- Submit as many cases as you like

- Enjoy fast sympathetic peer review and rapid publication of accepted articles

- Access all the published articles

- Re-use any of the published material for personal use and teaching without further permission

For information on Institutional Fellowships contact consortiasales@bmjgroup.com

Visit casereports.bmj.com for more articles like this and to become a Fellow 